Рекомендована д. фрармац. наук, профр. Л. М. Унгурян

УДК 614.876:614.273:34

DOI 10.11603/2312-0967.2018.3.9374

\title{
АНАЛІЗ НОРМАТИВНО-ПРАВОВОЇ БАЗИ ФАРМАЦЕВТИЧНОГО ЗАБЕЗПЕЧЕННЯ НАСЕЛЕННЯ В УМОВАХ ЛІКВІДАЦІЇ НАСЛІДКІВ РАДІАЦІЙНИХ АВАРІЙ
}

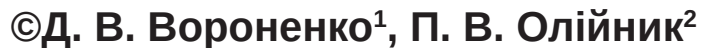

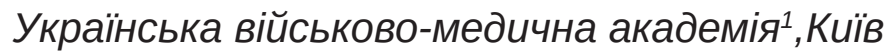 \\ Львівський національний медичний університет імені Данила Галицького \\ dvork226@ukr.net
}

\begin{abstract}
Мета роботи. Аналіз сучасного стану законодавчих і нормативно-правових актів у галузі радіаційної безпеки та обґрунтування необхідності вдосконалення нормативної бази з організації фармацевтичного забезпечення населення в умовах надзвичайних ситуацій радіаційного походження.

Матеріали і методи. У роботі використано законодавчі акти та нормативно-правові документи в галузі радіаційної безпеки, які стосуються фрармацевтичного забезпечення населення в умовах надзвичайних ситуацій радіаційного походження в Україні і зарубіжних країнах. Використовували методи системного підходу, бібліографрічного аналізу і контент-аналізу.

Результати й обговорення. Проведено аналіз сучасного стану законодавчих та нормативно-правових актів і методичних матеріалів у галузі радіаційної безпеки населення України щодо засад державного управління 3 організації повного і своєчасного постачання лікарняних закладів і медичних формувань лікарськими засобами та предметами медичного призначення для профрілактики і лікування радіаційних уражень у період ліквідації наслідків радіаційних аварій.

Висновки. На основі проведених досліджень встановлено, що нормативно-правового врегулювання потребують питання фрармацевтичного забезпечення профрілактики і лікування радіаційних уражень в період ліквідації наслідків радіаційних аварій мирного і воєнного часу. Необхідне наукове обґрунтування нових концептуальних підходів щодо вдосконалення системи фармацевтичного забезпечення радіаційної безпеки населення при перегляді вітчизняної нормативної бази і приведенні її до вимог документів міжнародних організацій.
\end{abstract}

Ключові слова: фрармацевтичне забезпечення; державне управління; нормативно-правовий акт; радіаційна безпека; радіаційна аварія; профрілактика і лікування радіаційних уражень.

Вступ. Розвиток атомної енергетики та її практичне застосування в Україні призвели до появи значної кількості ядерних реакторів на атомних електричних станціях (AEC) та джерел іонізуючого випромінювання (ДІВ) - наукових, промислових та інших радіаційних об'єктів, які характеризуються потенційною небезпекою виникнення радіаційних аварій (РА). Згідно 3 вимогами Закону України «Про використання ядерної енергії та радіаційну безпеку», під поняттям ДІВ розуміють - фрізичний об'єкт, крім ядерних установок, що містить радіоактивну речовину, або технічний пристрій, який створює або за певних умов може створювати іонізуюче випромінювання $[1,2]$. Потенційна небезпека радіаційних об'єктів може бути реалізована як через об'єктивні обставини, так і помилкові дії персоналу. Згідно з даними Державного регістру джерел іонізуючого випромінювання в Україні зареєстровано 27544 джерела, у тому числі 15880 радіонуклідних джерел і 11664 генератори випромінювання [3, 4].

Під поняттям РА розуміється подія, внаслідок якої втрачено контроль над ядерною установкою або ДІВ і яка призводить або може призвести до радіаційного впливу на людей та навколишнє природне середовище, який перевищує межі, встановлені нормами, стандартами і правилами безпеки [5, 6, 7, 8]. Особливість радіоактивного іонізуючого випромінювання полягає в тому, що людина не відчуває небезпеки для свого здоров'я під час його впливу. Окрім того, РА спричинює тривале радіаційне забруднення значних територій, очищення яких від впливу радіаційних чинників на людей та навколишнє природне середовище потребує значних зусиль і матеріальних затрат протягом тривалого часу.

Заходи щодо аварійного реагування повинні включати не тільки комплекс інфраструктурних елементів для забезпечення здатності виконувати заздалегідь визначені завдання, які необхідні у випадках виникнення РА $[9,10,11]$. Вони повинні включати основні, науково обґрунтовані, положення фрармацевтичного забезпечення населення в умовах НC paдіаційного походження, які містять чітко визначені обов'язки і повноваження центральних і місцевих ор-

ISSN 2312-0967. Pharmaceutical review. 2018. № 3 
Організація роботи аптечних підприємств Organization of pharmaceutical structures' work

ганів влади з організації повного і своєчасного постачання лікарняних закладів і медичних формувань лікарськими засобами та предметами медичного призначення для профрілактики і лікування радіаційних уражень.

Отже, метою роботи є аналіз сучасного стану законодавчих та нормативно-правових актів і методичних матеріалів у галузі радіаційної безпеки та наукове обґрунтування необхідності вдосконалення нормативної бази з організації фармацевтичного забезпечення населення в умовах НС радіаційного походження.

Матеріали і методи. У роботі використано законодавчі акти та нормативно-правові документи в галузі радіаційної безпеки, які стосуються фрармацевтичного забезпечення населення в умовах НС радіаційного походження в Україні і зарубіжних країнах. Використовували методи системного підходу, бібліографрічного аналізу і контент-аналізу.
Результати й обговорення. На сучасному етапі розвитку суспільства радіоактивні речовини широко застосовують у промисловості, медицині, військовій сорері. Станом на початок 2018 р. у світі експлуатується 451 ядерний реактор [12]. Україна входить до першої десятки держав із розвиненою ядерною енергетикою. На чотирьох AEC експлуатують 15 енергоблоків потужністю 13835 МВт. У Києві та Севастополі експлуатують дослідницькі ядерні реактори, на Запорізькій AEC - сховище відпрацьованого ядерного палива «сухого типу». Функціонує 6 регіональних спеціалізованих підприємств із поводження 3 радіоактивними відходами у складі Державної корпорації «УкрДО «Радон». У Дніпропетровській та Кіровоградській областях видобувають та переробляють уранові руди [13]. На відстані менше 1000 км від кордонів України розташовані 28 АEC європейських країн (табл. 1) [14].

Наявність значної кількості ДІВ і ядерних установок в Україні та поблизу її кордонів є потенційною не-

Таблиця 1. Перелік АEC, які розташовані на відстані до 1000 км від кордонів України

\begin{tabular}{|c|c|c|}
\hline № 3/п & Назва AEC & Приблизна відстань від АЕС до населеного пункту, км \\
\hline 1 & Козлодуй, Болгарія & 448 (Ізмаїл) \\
\hline 2 & Арсенія, Вірменія & 852 (Керч) \\
\hline 3 & Ігналіна, Литва & 423 (Зарічне) \\
\hline 4 & Брокдорф, ФРН & 588 (Ужгород) \\
\hline 5 & Графренрейнфельд, ФРН & 890 (Ужгород) \\
\hline 6 & Гронде, ФРН & 988 (Ужгород) \\
\hline 7 & Гундремінген, ФРН & 874 (Ужгород) \\
\hline 8 & Icap, ФPH & 734 (Ужгород) \\
\hline 9 & Кромвель, ФРН & 983 (Ужгород) \\
\hline 10 & Нескарвезіхейм, ФРН & 961 (Ужгород) \\
\hline 11 & Одріхейм, ФРН & 966 (Ужгород) \\
\hline 12 & Балаковська, РФ & 950 (Шостка) \\
\hline 13 & Калінінська, РФ & 680 (Шостка) \\
\hline 14 & Курська, РФ & 147 (Шостка) \\
\hline 15 & Ленінградська, РФ & 928 (Шостка) \\
\hline 16 & Нововоронєжська, РФ & 400 (Шостка) \\
\hline 17 & Смоленська, РФ & 256 (Шостка) \\
\hline 18 & Волгодонська, РФ & 783 (Шостка) \\
\hline 19 & Чернавода, Румунія & 132 (Ізмаїл) \\
\hline 20 & Богуніце, Словаччина & 340 (Ужгород) \\
\hline 21 & Мохове, Словаччина & 287 (Ужгород) \\
\hline 22 & Кришко, Словенія & 592 (Ужгород) \\
\hline 23 & Пакш, Угорщина & 345 (Ужгород) \\
\hline 24 & Ловіза, Фінляндія & 973 (Ратне) \\
\hline 25 & Дуковані, Чехія & 454 (Ужгород) \\
\hline 26 & Темелін, Чехія & 590 (Ужгород) \\
\hline 27 & Барсебак, Швеція & 924 (Ковель) \\
\hline 28 & Оскардам, Швеція & 814 (Ратне) \\
\hline
\end{tabular}

ISSN 2312-0967. Фармацевтичний часопис. 2018. № 3 
безпекою виникнення РА. Цьому сприяє ряд чинників, до яких належать постійна терористична загроза внаслідок подій на Сході України та застарілість конструкцій і технологій, що використовуються на АЕС.

В Україні спостерігається тенденція до збільшення випадків виявлення ДІВ, за якими втрачено контроль (від 9 - 10 в рік на початку 1990-х рр. до 21 - 42 в останні роки), що свідчить про можливість виникнення РА і неконтрольованого опромінення населення [15]. За останні 20 років в Україні зареєстровано 365 РА. Виявлено, що найбільша кількість РА відбувається 3 промисловими ДІВ, що сконцентровані в Донецькій (44,4 \%), Дніпропетровській (8,5 \%), Запорізькій (7,4 \%) Луганській областях (6,8 \%) [15]. Встановлено, що максимальна кількість РА сталася через порушення радіаційного контролю (52,6 \%), значна кількість яких пов'язана з ліквідацією або перепрофрілюванням підприємств, крадіжку ДІВ (30,7 \%), втрату ДІВ (5,5 \%), з технологічних причин (4,9\%), внаслідок незаконного обігу ДІВ $(3,6 \%)[5,6]$.

Використання рентгенівських апаратів призводить до зростання рівня медичного опромінення населення. Так, за оцінками Наукового Комітету ООН 3 дії атомної радіації середньосвітова річна ефективна доза опромінення на душу населення за рахунок медичного опромінення дорівнює 0,4 мЗв, що складає 7,7 \% сумарної дози опромінення населення [16, 17]. В Україні доза опромінення від застосування рентгенівських апаратів складає 0,5 м3в на рік, що дорівнює 7 \% від усієї дози опромінення населення [18].

Реагування на РА на діючих АЕC передбачені аварійними планами АЕС України, Планом аварійного реагування Дирекції ГП НАЕК «Енергоатом» і регламентовані НП-306.5.01/3.083-2004 «План реагування на радіаційні аварії» Держатомрегулювання та Державної служби $з$ надзвичайних ситуацій (ДСНС) України $[19,20]$.

Закони України «Про використання ядерної енергії та радіаційну безпеку» та «Про захист людини від впливу іонізуючого випромінювання» встановлюють обов'язки керівництва AEC про своєчасне інфрормування місцевих органів виконавчої влади щодо виникнення РА, порушень технологічних регламентів, які створюють загрозу для безпеки людини та надання цим органам рекомендацій щодо захисту населення. Ці вимоги реалізовані у Плані реагування на радіаційні аварії (НП-306.5.01/3.083-2004), який визначає обов'язки кожного з учасників реагування на PA, у тому числі і МОЗ України та інших центральних органів виконавчої влади, які залучаються до реагування у випадку РА та визначені «Положенням про єдину державну систему цивільного захисту», затвердженим Постановою Кабінету Міністрів України № 11 від 09.01.2014 р. [20, 21, 22].

Залучення виконавців до усіх робіт в умовах РА регламентоване також Нормами радіаційної безпеки України (НРБУ-97): ці роботи повинен виконувати персонал, підготовлений до робіт в умовах РА. При цьому залучення персоналу до усіх видів робіт в умовах підвищеного опромінення повинно здійснюватись виключно на добровільній основі при документально підтвердженій відсутності будь-яких протипоказань за станом здоров'я, надання відповідної письмової згоди та отримання встановленим порядком допуску до виконання таких робіт [19, 23, 24]. Аналогічні вимоги містять Основні санітарні правила забезпечення радіаційної безпеки України (ДСП 6.1772005-09-02), затверджені наказом МО3 України № 54 від 02.02.2005 р. [25].

Міжнародне агенство з атомної енергії (МАГАТЕ), у своїх документах, які стосуються готовності та реагування у випадку РА, вимагає чіткого визначення повноважень і відповідальності за прийняття рішень щодо вжитих заходів аварійного реагування, які повинні оперативно виконуватися після надходження оповіщення про аварійну ситуацію [26].

Порядок організації та здійснення невідкладних заходів у випадку виникнення РА регламентовані «Зразковим планом реагування на радіаційні аварії територіальних підсистем ЄС ЦЗ, вся або частина території яких належить до зони спостереження AEC». У випадку РА на діючих АЕС України органи центральної та місцевої влади повинні приймати рішення й діяти на підставі відповідних відомчих і територіальних планів, з урахуванням рекомендацій AEC [19]. Зокрема, відповідно до вимог Закону України «Про захист людини від впливу іонізуючого випромінювання» та Кодексу цивільного захисту України, підприємства, які експлуатують об'єкти категорії радіаційної небезпеки повинні створювати резерви медичного майна і лікарських засобів (ЛЗ) для захисту персоналу об'єктів радіаційної небезпеки та осіб, які перебувають у санітарно-захисній зоні, організацію і координацію робіт із надання медичної допомоги постраждалому персоналу $[27,28]$.

Проведений аналіз сучасного стану законодавчих та нормативно-правових документів і методичних матеріалів свідчить про те, що в Україні відсутній єдиний державний регулюючий орган у галузі радіаційної безпеки та протирадіаційного захисту населення. Вирішення цих питань покладене на Державну інспекцію ядерного регулювання України (Держатомрегулювання), Державну службу України з питань надзвичайних ситуацій (ДСНС), Державний комітет України 3 питань технічного регулювання та споживчої політики (Держспоживстандарт), Міністерство екології та природних ресурсів України та Міністерство охорони здоров'я України. Проведений аналіз свідчить про відсутність чіткого розподілу законодавчих і нормативно визначених фрункцій між цими структурами. Особливо це стосується питань організації фрармацевтичного забезпечення заходів щодо профрілактики радіаційних уражень і лікування постраждалого населення.

ISSN 2312-0967. Pharmaceutical review. 2018. № 3 
Організація роботи аптечних підприємств

Organization of pharmaceutical structures' work

Відповідно до вимог Закону України «Про захист людини від впливу іонізуючого випромінювання», 3 метою обліку та контролю доз опромінення персоналу та населення в Україні повинна бути створена Єдина державна система контролю та обліку індивідуальних доз опромінення. Координацію робіт зі створення системи покладено на Міністерство охорони здоров'я України. Проте до сьогодні такої системи не створено [29, 30].

На сьогодні в Україні відсутній науково обґрунтований перелік Лз і предметів медичного призначення, необхідних для профрілактики і лікування радіаційних уражень, не визначений порядок їх накопичення, зберігання та застосування в умовах ліквідації наслідків РА.

Постанови Кабінету Міністрів України № 1200 від 19.08.2002 р. і № 775 від 30.09.2015 р. визначають механізм та шляхи забезпечення населення і служб цивільного захисту засобами радіаційного та хімічного захисту будівельними і паливно-мастильними матеріалами, продуктами харчування та іншими матеріальними цінностями у випадку застосування ядерної та інших видів зброї масового знищення проти України в умовах воєнного стану або у випадку виникнення НС на радіаційно та хімічно небезпечних об'єктах в умовах мирного часу. Перелік лз і предметів медичного призначення, необхідних для профілактики лікування радіаційних уражень, у цих нормативних документах відсутній [31, 32].

3 метою профрілактики радіаційних уражень внаслідок РА, для захисту щитоподібної залози від накопичення радіоактивного йоду Всесвітньою організацією охорони здоров'я після Чорнобильської катастрофри були видані керівництва з йодної профрілактики [33, 34, 35]. Наказом Держатомрегулювання № 154 від 08. 11. 2011 р., погодженим із МОЗ України, введено в дію «Порядок здійснення невідкладних заходів йодної профрілактики серед населення України у разі виникнення радіаційної аварії». Відповідно до вимог цього наказу Регламент проведення йодної профрілактики встановлюється МОЗ України, проте цей Регламент до сьогодні не розроблений і в Україні відсутній [36, 37, 38].

Проведений аналіз сучасного стану законодавчих та нормативно-правових актів і методичних матеріалів у галузі радіаційної безпеки населення свідчить про відсутність в Україні науково обґрунтованих положень фрармацевтичного забезпечення населення в умовах НС радіаційного походження, які повинні включати чітко визначені обов'язки і повноваження центральних і місцевих органів влади з організації повного і своєчасного постачання лікарняних закладів і медичних формувань лікарськими засобами та предметами медичного призначення для профрілактики і лікування радіаційних уражень.

Таким чином, враховуючи практичну відсутність законодавчої і нормативно-правової бази для регулювання фрармацевтичного забезпечення радіаційної безпеки та протирадіаційного захисту населення України, одним із важливих напрямків діяльності в цій сорері $€$ фрормування і наукове обґрунтування законодавчих і нормативних актів у цій галузі з урахуванням сучасних міжнародних підходів.

Висновки. 1. Аналіз сучасного стану законодавчих та нормативно-правових актів і методичних матеріалів у галузі радіаційної безпеки населення України свідчить про відсутність засад державного управління щодо організації повного і своєчасного постачання лікарняних закладів і медичних фрормувань лікарськими засобами та предметами медичного призначення для профілактики і лікування радіаційних уражень у період ліквідації наслідків радіаційних аварій. В Україні відсутній єдиний державний регулюючий орган, до функцій якого було би віднесено формування єдиної нормативної бази державного управління фрармацевтичним забезпеченням постраждалого населення в умовах НС радіаційного походження у мирний та воєнний час.

2. Потребують законодавчого і нормативноправового врегулювання питання щодо права громадян на повне і безперебійне фрармацевтичне забезпечення профрілактики і лікування радіаційних уражень в період ліквідації наслідків радіаційних аварій мирного і воєнного часу. Потребує розробки і наукового обґрунтування порядок накопичення, зберігання та застосування переліку лікарських засобів і предметів медичного призначення, необхідних для профрілактики і лікування радіаційних уражень в умовах НС радіаційного походження у мирний та воєнний час.

3. Необхідне наукове обґрунтування нових концептуальних підходів щодо вдосконалення системи фрармацевтичного забезпечення радіаційної безпеки населення при перегляді вітчизняної нормативної бази і приведенні її до вимог документів міжнародних організацій.

ISSN 2312-0967. Фармацевтичний часопис. 2018. № 3 
Організація роботи аптечних підприємств

Organization of pharmaceutical structures' work

\title{
АНАЛИЗ НОРМАТИВНО-ПРАВОВОЙ БАЗЫ ФАРМАЦЕВТИЧЕСКОГО ОБЕСПЕЧЕНИЯ НАСЕЛЕНИЯ В УСЛОВИЯХ ЛИКВИДАЦИИ ПОСЛЕДСТВИЙ РАДИАЦИОННЫХ АВАРИЙ
}

\author{
Д. В. Вороненко르, П. В. Олийнык² \\ Украинская военно-медицинская академия ${ }^{1}$ Киев \\ Львовский национальный медицинский университет имени Данила Галицкого \\ dvork226@ukr.net
}

Цель работы. Анализ современного состояния законодательных и нормативно-правовых актов в области радиационной безопасности, обоснование необходимости совершенствования нормативной базы по организации фрармацевтического обеспечения населения в условиях чрезвычайных ситуаций радиационного происхождения.

Материалы и методы. В работе использованы законодательные акты и нормативно-правовые документы в области радиационной безопасности, касающиеся фармацевтического обеспечения населения в условиях чрезвычайных ситуаций радиационного происхождения в Украине и зарубежных странах. Использовались методы системного подхода, библиографического анализа и контент-анализа.

Результаты и обсуждение. Проведен анализ современного состояния законодательных и нормативно-правовых актов, а также методических материалов в области радиационной безопасности населения Украины относительно принципов государственного управления по организации полного и своевременного снабжения лечебных учреждений и медицинских фрормирований лекарственными средствами и предметами медицинского назначения для профрилактики и лечения радиационных поражений в период ликвидации последствий радиационных аварий. Выводы. На основе проведенных исследований установлено, что нормативно-правового регулирования требуют вопросы фрармацевтического обеспечения профилактики и лечения радиационных поражений в период ликвидации последствий радиационных аварий мирного и военного времени. Необходимо научное обоснование новых концептуальных подходов по совершенствованию системы фрармацевтического обеспечения радиационной безопасности населения при просмотре отечественной нормативной базы и приведении ее к требованиям документов международных организаций.

Ключевые слова: фрармацевтическое обеспечение; государственное управление; нормативно-правовой акт; радиационная безопасность; радиационная авария; профрилактика и лечение радиационных поражений.

\section{ANALYSIS OF THE NORMATIVE LEGAL BASIS OF PHARMACEUTICAL ENSURING OF THE POPULATION UNDER THE CONDITIONS OF ELIMINATING THE CONSEQUENCES OF RADIATION ACCIDENTS}

\author{
D. V. Voronenko ${ }^{1}$, P. V. Oliynyk ${ }^{2}$ \\ Ukrainian Military Medical Academy ${ }^{1}$, Kyiv \\ Danylo Halytsky Lviv National Medical University² \\ dvork226@ukr.net
}

The aim of the work. Analysis of the current state of legislative and regulatory acts in the field of radiation safety, the rationale for the need to improve the regulatory framework for the organization of pharmaceutical provision of the population in emergency situations of radiation origin.

Materials and Methods. The work used legislative acts and regulatory documents in the field of radiation safety related to pharmaceutical provision of the population in emergency situations of radiation origin in Ukraine and foreign countries. Methods of the system approach, bibliographic analysis and content analysis were used.

Results and Discussion. The analysis of the current state of legislative and regulatory acts as well as methodological materials in the field of radiation safety of the population of Ukraine regarding the principles of state administration for the organization of complete and timely provision of medical facilities and medical units with medicines and medical supplies for the prevention and treatment of radiation injuries in the period elimination of the consequences of radiation accidents. Conclusions. On the basis of the conducted researches it is established that the issues of pharmaceutical provision for the prevention and treatment of radiation injuries during the liquidation of the consequences of radiation accidents of civil and military time are required for regulatory legal regulation. It is necessary to scientifically substantiate new conceptual approaches to improve the system of pharmaceutical provision of radiation safety of the population when viewing the domestic regulatory framework and bringing it to the requirements of documents of international organizations.

Key words: pharmaceutical supply; public administration; legal act; radiation safety; radiation accident; prevention and treatment of radiation damage.

ISSN 2312-0967. Pharmaceutical review. 2018. № 3 
Організація роботи аптечних підприємств

Organization of pharmaceutical structures' work

\section{Список літератури}

1. Про використання ядерної енергії та радіаційну безпеку : Закон України // Відомості Верховної Ради України. - 1995. - № 12. - С. 81. - [Електронний ресурс]. - Режим доступу: http://zakon1.rada.gov.ua/rada/ show/39/95вр Дата доступу: 02.07.2018 р.

2. Про дозвільну діяльність у сорері використання ядерної енергії : Закон України // Відомості Верховної Ради України. - 2000. - № 9. - С. 68. - [Електронний ресурс]. - Режим доступу: http://zakon3.rada.gov.ua/laws/ show /1370-14/paran18\#n18 Дата доступу: 02.07.2018 р. 3. Севальнєв А. І. Радіаційне навантаження персоналу, що працює 3 джерелами іонізуючого випромінювання / А. І. Севальнєв, М. І. Костенецький, А. В. Куцак // Матеріали XV з'їзду гігієністів України. - Львів, 2012. - С. 358359.

4. Державний регістр джерел іонізуючого випромінювання [Електронний ресурс]. - Режим доступу : https:// uatom.org/index.php/derzhavnij-registr-div/ Дата доступу: 02.07.2018 p.

5. Мурашко В. О. Промислові радіаційні аварії 3 джерелами іонізуючого випромінювання, запобігання та порядок їх розслідування / В. О. Мурашко, М. І. Костенецький, Л. В. Рущак. - К. , 2013. - 82 с.

6. Радиационная авария. Экологический словарь [Електронний ресурс]. - Режим доступу : http://www. ecosystema.ru/07referats/slovar/16r.php Дата доступу: 02.07.2018 p.

7. Radiation protection and safety of radiation sources: International basic safety standards - Interim edition International Atomic Energy Agency, Austria, Vienna 2011. 329 p. [Electronic source]. - Mode access: http://www.ilo.org/ safework/info/publications/WCMS_171036/lang--en/index. htm Дата доступу: 02.07.2018 р.

8. Тарасюк О. Є. Використання терміну «Радіаційна аварія» в українських законодавчо-нормативних документах та міжнародних рекомендаціях / О. Є. Тарасюк, О. М. Цимбалюк // «Актуальні питання гігієни та екологічної безпеки України»: матеріали наук. - практ. конор. (Київ, 21 - 22 травня 2009 р.) / ДУ «Інститут гігієни та медичної екології ім. О. М. Марзєєва АМН України». - К., 2009. - С. 34-36.

9. Ядерная безопасность при ликвидации последствий тяжелой аварии на ЧАЭС / Е. Д. Высотский, Р. Л. Годун, А. А. Дорошенко, В. А. Краснов // Проблеми безпеки атомних електростанцій і Чорнобиля. - 2017. - Вип. 28. - C. 60-67.

10. Глоссарий МАГАТЭ по вопросам радиационной безопасности. МАГАТЭ. - Вена. - 2008. - 295 с. [Електронний ресурс]. - Режим доступу : https://docplayer.ru/25964549-Glossariy-magate-po-voprosam-bezopasnosti.html Дата доступу: 02.07.2018 p.

11. Категоризация радиоактивных источников. Серия норм по безопасности № RS-G-1.9.-МАГАТЭ. - Вена. 2005. $-122 \mathrm{c}$.

12. Power reactor information system. Operational \& longterm shutdown reactors [Electronic source]. - Mode access: https://www.iaea.org/PRIS /WorldStatistics/OperationalReactorsByCountry.aspx Access date: 02.07.2018 p. 13. Інфрормація про діяльність НАЕК «Енергоатом»
[Електронний ресурс]. - Режим доступу : http://mpe.kmu. gov.ua/minugol/control/publish /article?art_id=244916068 Дата доступу: 02.07.2018 p.

14. План реагування функціональної підсистеми єдиної державної системи запобігання і реагування на надзвичайні ситуації техногенного і природного характеру «Безпека об'єктів ядерної енергетики» : наказ Державного комітету ядерного регулювання України від 16.07.2010 р. № 93 [Електронний ресурс]. - Режим доступу : http://www.snrc.gov.ua/nuclear /uk/publish/article/140523 . Дата доступу: 02.07.2018 p.

15. Тарасюк О. Є. Наукове обґрунтування оптимальних обсягів нормативної бази в галузі радіаційної гігієни : автореф. дис. на здобуття наук. ступеня канд. мед. наук / О. Є. Тарасюк. - Київ, 2010. - 22 с.

16. Костенецький М. І. Стан радіаційної безпеки пацієнтів при рентгенологічних процедурах та шляхи їі вдосконалення / М. І. Костенецький // Актуальні питання забезпечення санітарного та епідемічного благополуччя населення Запорізької області в умовах рефрормування : зб. тез доповідей 54 НПК. - Запоріжжя. - 2014. - С. 2729.

17. UNSCEAR 2000. Effects of Radiation on the Environment; Report to the General Assembly with Scientists Annex / United nations Scientific Committee on the Effects of Atomic Radiation. New York. UN, 2000, 842 p. [Electronic source]. - Mode access: http://www.unscear.org/unscear/ publications.html Access date: 04.07.2018 p.

18. Сердюк А. М. Проблеми сьогодення та шляхи їх подолання. Гігієнічна наука та практика на рубежі століть / А. М. Сердюк, І. П. Лось // Матеріали XIV з'їзду гігієністів України. - Дніпропетровськ. - 2004. - Т. 2, С. 303-305.

19. Аварійна готовність і реагування. Механізм аварійного реагування в разі ядерної або радіологічної аварійної ситуації. - Київ : ДП НАЕК «Енергоатом», 2018. - 26 с. - [Електронний ресурс]. - Режим доступу : http://www.energoatom.kiev.ua/ua/actvts/security_activities/emergency_preparedness_response/45065-avariyinaya_gotovnost_i_reagirovanie_mehanizm_avariyinogo_ reagirovaniya_v_šcuchae_yadernoyi_ili_radiologicheskoyi_avariyinoyi_situatcii/. Дата доступу: 04.07.2018 p.

20. План реагування на радіаційні аварії (НП-306.5.01/3.083-2004) : наказ Держатомрегулювання та МHC № 87/211 від 17.05.2004 р. [Електронний ресурс]. - Режим доступу : http://zakon0.rada.gov.ua/ laws/show/z0720-04 Дата доступу: 04.07.2018 p.

21. Про затвердження Плану реагування на надзвичайні ситуації державного рівня : Постанова КМУ № 223 від 14 березня 2018 р. [Електронний ресурс]. - Режим доступу : http://zakon0.rada.gov.ua/laws /show/en/2232018-\%D0\%BF Дата доступу: 04.07.2018 р.

22. Про затвердження Положення про єдину державну систему цивільного захисту : Постанова КМУ № 11 від 9 січня 2014 р. [Електронний ресурс]. - Режим доступу

http://zakon2.rada.gov.ua/laws/show/11-2014-\%D0\%BF Дата доступу: 04.07.2018 p.

23. Про затвердження державних санітарних правил «Основні санітарні правила забезпечення радіаційної

ISSN 2312-0967. Фармацевтичний часопис. 2018. № 3 
безпеки України» : Наказ МО3 України № 54 від 02.02.2005 р. [Електронний ресурс]. - Режим доступу : http://zakon2. rada.gov.ua/laws/show/z0552-05 Дата доступу: 04.07.2018 p.

24. Норми радіаційної безпеки України, доповнення: Радіаційний захист від джерел потенційного опромінення (НРБУ-97/Д-2000) : Постанова Головного державного санітарного лікаря України № 116 від 12.07.2000 р. [Електронний ресурс]. - Режим доступу : http://consultant.parus.ua/?doc= 052UL932A5 Дата доступу: 04.07.2018 p.

25. Про введення в дію Державних гігієнічних нормативів «Норми радіаційної безпеки України (НРБУ97)» : Постанова Головного державного санітарного лікаря України № 62 від 01.12.1997 р. [Електронний ресурс]. - Режим доступу : https://dnaop.com/html/43243/ doc\%D0\%94\%D0\%9D\%D0\% 90\%D0\%9E\%D0\%9F_-97 Дата доступу: 04.07.2018 p.

26. Готовность и реагирование в случае ядерной или радиологической аварийной ситуации. Общие требования безопасности. Серия норм безопасности МАГАТЭ IAEA-МАГАTE No. GSR Part 7. - Вена, 2016. 160 c. - [Електронний ресурс]. - Режим доступу : https:// wwwpub.iaea.org/MTCD/ Publications/PDF/P1708R_web. pdf Дата доступу: 04.07.2018 p.

27. Про затвердження Плану реагування на радіаційні аварії (Із змінами, внесеними згідно 3 Наказом Державного комітету ядерного регулювання № 24/126 від 02.03.2010 року) : наказ Державного комітету ядерного регулювання та МНС України №87/211 від 17.05.2004 р. [Електронний ресурс]. - Режим доступу : http://zakon0.rada.gov.ua/laws/show/z0720-04 Дата доступу:04.07.2018 p.

28. Кодекс цивільного захисту України [Електронний ресурс]. - Режим доступу : http://zakon.rada.gov.ua/laws/ show/5403-17 Дата доступу: 04.07.2018 p.

29. Тріпайло Р. Єдина державна система контролю та обліку індивідуальних доз опромінення [Електронний ресурс]. - Режим доступу : https://uatom.org/index. php/2018/03/14/yedina-derzhavna-sistemi-kontrolyu-taobliku-individualnih-doz-oprominennya-zadumana-v-90-hvtilyuyetsya-sogodni/ Дата доступу:04.07.2018 p.

30. Про захист людини від впливу іонізуючого випромінювання : Закон України // Відомості Верховної Ради України. - 1998. - № 22. - С. 115. [Електронний ресурс]. - Режим доступу: http://zakon2. rada.gov.ua/laws/showl 15/98-\%D0\%B2\%D1\%80 Дата доступу:04.07.2018 p.

\section{References}

1. The Law of Ukraine "On the Use of Nuclear Energy and Radiation Safety". Vidomosti Verkhovnoi Rady Ukrainy.1995.12.81. [Electronic resource]. Available from: http://zakon1.rada.gov.ua/rada/show/39/95-vr. Ukrainian.

2. The Law of Ukraine "On Permitting Activities in the Field of Nuclear Energy Utilization". Vidomosti Verkhovnoi Rady Ukrainy.2000.9.68. [Electronic resource]. Available from: http://zakon3.rada.gov.ua/laws/show /1370-14/ paran18\#n18. Ukrainian.
31. Про затвердження Порядку забезпечення населення і працівників формувань та спеціалізованих служб цивільного захисту засобами індивідуального захисту, приладами радіаційної та хімічної розвідки, дозиметричного і хімічного контролю : Постанова Кабінету Міністрів України від 19.08.2002 р. № 1200 (У редакції від 27.05.2017р.) [Електронний ресурс]. - Режим доступу : http://zakon2.rada.gov.ua/laws/ show/1200-2002-п Дата доступу: 04.07.2018 p.

32. Про затвердження Порядку створення та використання матеріальних резервів для запобігання і ліквідації наслідків надзвичайних ситуацій : Постанова Кабінету Міністрів України від 30.09.2015 р. № 775 (Редакція від 03.05.2018) [Електронний ресурс]. - Режим доступу : http://zakon.rada.gov.ua/laws/show/775-2015-п Дата доступу:04.07.2018 p

33. Guidelines for iodine prophylaxis following nuclear accidents. World Health Organization. Regional Office for Europe.Copenhagen : FADL, 1989. - [Електронний ресурс]. - Режим доступу: https://trove.nla.gov.au/work/5766789? q\&versionld=6704323 Дата доступу: 02.07.2018 p.

34. Guidelines for lodine Prophylaxis following Nuclear Accidents. Update 1999. World Health Organization, Geneva, 1999 (WHO/SDE/PHE/99. 6). -[Electronic source]. - Mode access: http://www.who.int/ionizing_radiation/ pub_meet/lodine_Prophylaxis_guide. pdf. Дата доступу: 02.07.2018 p.

35. Актуальні проблеми йодної профрілактики в Україні на випадок радіаційної аварії на АЕС: Аналітична записка Національний інститут стратегічних досліджень [Електронний ресурс]. - Режим доступу : http://www.niss. gov.ua/articles/2374/ Дата доступу: 02.07.2018 p.

36. Скалецький Ю. М. Проблеми йодної профілактики в Україні на випадок радіаційної аварії на атомній електростанції / Ю. М.Скалецький, В. Л.Савицький, В. П. Печиборщ // Вісник проблем біології і медицини. - 2014. - Вип. 3, Т 1. - С. 321-325.

37. Проблемы проведения йодной профилактики при аварии на ядерном блоке АЭС / С. Ф. Гончаров, Г. М. Аветисов, А. М. Сердюк [та ін.] // Довкілля та здоров'я. - 2013. - № 1. - С. 12-19.

38. Про затвердження Порядку здійснення невідкладних заходів йодної профрілактики серед населення України у разі виникнення радіаційної аварії : наказ Державної інспекції ядерного регулювання України № 154 від 08.11.2011 р. [Електронний ресурс]. - Режим доступу: http://zakon2.rada. gov.ua/laws/show/z1353-11 Дата доступу: 02.07.2018 p

3. Sevalniev AI, Kostenetskyi MI, Kutsak AV. Radiation load of personnel working with sources of ionizing radiation. Materialy XV zizdu hihiienistiv Ukrainy. Lviv. 2012. 358-9. Ukrainian.

4. State register of sources of ionizing radiation. [Electronic resource]. Available from: https://uatom.org/index.php/derzhavnij-registr-div. Ukrainian.

5. Murashko VO, Kostenetskyi MI, Rushchak LV. Industrial radiation accidents with sources of ionizing radiation, preven-

ISSN 2312-0967. Pharmaceutical review. 2018. № 3 
Організація роботи аптечних підприємств Organization of pharmaceutical structures' work

tion and order of their investigation. [Промислові радіаційні аварії 3 джерелами іонізуючого випромінювання, запобігання та порядок їх розслідування] Kyiv; 2013. Ukrainian.

6. Radiation accident. Ecological dictionary. [Electronic resource]. Available from: http://www.ecosystema. ru/07referats/slovar/16r.php. Russian.

7. Radiation protection and safety of radiation sources: International basic safety standards - Interim edition International Atomic Energy Agency, Austria, Vienna; 2011. [Electronic resource]. Available from: http://www.ilo.org/ safework/info/publications/WCMS_171036/lang--en/index. htm. Ukrainian.

8. Tarasiuk OYe, Tsymbaliuk OM. Use of the term "Radiation Accident" in Ukrainian legislation and international recommendations. Actual questions of hygiene and ecological safety of Ukraine: materials of scien.-practical conference, 2009 May 21-2; Kyiv. Kyiv: O. Marzieiev Institute of Hygiene and Medical Ecology; 2009. P. 34-6. Ukrainian.

9. Vysotskiy ED, Godun RL, Doroshenko AA., Krasnov VA. Nuclear safety in the aftermath of the severe Chernobyl accident. Problemy bezop atomnykh elektrostantsiy i Chernobylya. 2017;28: 60-7. Russian.

10. IAEA Glossary on Radiation Safety. MAGATE. [Глоссарий МАГАТЭ по вопросам радиационной безопасности. МАГАТЭ]Vena; 2008 [Electronic resource] Available from: https://docplayer.ru/25964549-Glossariymagate- po-voprosam-bezopasnosti.html. Russian.

11. Categorization of radioactive sources. Safety Standards Series No. RS-G-1.9.-IAEA. Vena; 2005. Russian.

12. Power reactor information system. Operational \& longterm shutdown reactors. [Electronic resource]. Available from: https://www.iaea.org/PRIS /WorldStatistics/OperationalReactorsByCountry.aspx

13. Information on the activities of NNEHC "Enerhoatom". [Electronic resource]. Available from: http://mpe.kmu.gov. ua/minugol/control/publish /article?art_id= 244916068 . Ukrainian.

14. Order of the State Nuclear Regulatory Committee of Ukraine dated July 16, 2010 No. 93. "On response plan of the functional subsystem of the unified state system of prevention and response to emergency situations of anthropogenic and natural character "Safety of nuclear facilities". Available from: http://www.snrc.gov.ua/nuclear/en/publish/ article/140523. Ukrainian.

15. Tarasyuk OYe. Scientific substantiation of the optimum volumes of normative base in the field of radiation hygiene. Candidate's Extended abstract. Kyiv: Instytut hihiieny ta medychnoi ekoloii imeni O.M. Marzieieva AMN Ukrainy; 2010. 22 p. Ukrainian.

16. Kostenetskyi MI. The state of radiation safety of patients with radiological procedures and ways of its improvement. Topical issues of ensuring the sanitary and epidemiological well-being of the population of Zaporizhzhia oblast in the conditions of reforming. Collection of reports of 54 NPK. Zaporizhzhia; 2014. p. 27-9. Ukrainian.

17. UNSCEAR 2000. Effects of Radiation on the Environment; Report to the General Assembly with Scientists Annex / United nations Scientific Committee on the Effects of Atomic Radiation. New York. UN, 2000, 842 p. [Electronic resource]. Available from: http: www.unscear.org/unscear/ publications.html

18. Serdiuk AM, Los IP. Problems of the present and ways to overcome them. Hygienic science and practice at the turn of the century. Materials of the XIV Congress of Hygienists of Ukraine. Dnipropetrovsk; 2004. 2. 303-5. Ukrainian.

19. Emergency preparedness and response. Emergency response mechanism in case of a nuclear or radiological emergency. Kyiv: DP NAEK "Energoatom"; 2018. [Electronic resource]. Available from: http:www.energoatom.kiev.ua I...lavar_yna_gotovn_st_reaguvan. Ukrainian.

20. Order of the State Atom Regulation and Ministry of Emergency No. 87/211dated May 17, 2004 [Electronic resource]. Available from: http://zakon0.rada.gov.ua/laws/ show/z0720-04. Ukrainian.

21. Decree of KMU No. 223 "On approval of the Emergency Response Plan at the state level" dated March 14, 2018. [Electronic resource]. Available from: http:// zakon0.rada. gov.ua/laws /show/en/223-2018-\%D0\%BF. Ukrainian.

22. Decree of KMU No. 11 "On Approval of the Regulation on a Unified State Civil Protection System" dated January 9, 2014. [Electronic resource] - Available from: http://zakon2.rada.gov.ua/laws/show/11-2014-\%D0\%BF. Ukrainian. 23. Order of the Ministry of Health of Ukraine "On Approval of State Sanitary Rules "Basic Sanitary Rules of Radiation Safety of Ukraine" No. 54 dated February 2, 2005. [Electronic resource]. Available from: http://zakon2.rada.gov.ua/ laws/show/z0552-05. Ukrainian.

24. Decree of the Chief Sanitary Doctor of Ukraine No. 115, dated July 12, 2000 "On Radiation Safety Standards of Ukraine, Supplement: Radiation Protection from Sources of Potential Exposure (NRBU-97 / D-2000). [Electronic resource]. Available from: http://consultant.parus.ua/?doc= 052UL932A5. Ukrainian.

25. Decree of the Chief Sanitary Doctor of Ukraine No. 62, dated December 12, 1997 "On the Introduction into Operation of the State Hygienic Norms "Radiation Safety Standards of Ukraine (NRBU-97)". [Electronic resource]. Available from: https://dnaop.com/html/43243/ doc\%D0\%94\%D0\%9D\% D0\%90\%D0\%9E\%D0\%9F_-97. Ukrainian.

26. Readiness and response in the event of a nuclear or radiological emergency. General safety requirements. IAEA Safety Standards Series GSR Part 7.Vena, 2016. [Electronic resource]. Available from: https://wwwpub.iaea.org / MTCD/ Publications/PDF/P1708R_web.pdf. Russian.

27. Order of the State Nuclear Regulatory Committee and Ministry of Emergency of Ukraine No.87, dated May 17, 2004 "On Approval of the Response Plan for Radiation Accidents. [Electronic resource]. Available from: http://zakon0. rada.gov.ua/laws/show/z0720-04. Ukrainian.

28. Code of Civil Protection of Ukraine. Vidomosti Verkhovnoi Rady. 2013; 34-35. [Electronic resource]. Available from: http://zakon0.rada.gov.ua/laws/ show/5403-17. Ukrainian.

29. Tripajlo R. A single state system for monitoring and recording individual radiation doses. [Electronic resource]. Available from: https://uatom.org/index .php/2018/03/14/ yedina-derzhavna-sistemi-kontrolyu-ta-obliku-individualnih-doz-oprominennya-zadumana-v-90-h-vtilyuyetsya-sogodni/ Ukrainian.

ISSN 2312-0967. Фармацевтичний часопис. 2018. № 3 
30. The Law of Ukraine "On Protection of Human Rights from the Influence of Ionizing Radiation". Vidomosti Verkhovnoi Rady Ukrainy; 1998. [Electronic resource]. Available from: http://zakon2.rada.gov.ua/laws/show/ 15/98-\%D0\%B2\%D1\%80. Ukrainian.

31. Decree of the Cabinet of Ministers of Ukraine dated August 192002 "On Approval of the Procedure for Provision of Population and Staff Formations and Specialized Civil Protection Services by Personal Protective Equipment, Instruments of Radiation and Chemical Intelligence, Dosimetry and Chemical Control". [Electronic resource]. Available from: http://zakon2.rada.gov.ua/ laws/ show/ 1200-2002-п. Ukrainian.

32. Decree of the Cabinet of Ministers of Ukraine dated September 302015 "On Approval of the Procedure for the Creation and Use of Material Reserves for the Prevention and Elimination of Consequences of Emergencies". [Electronic resource]. Available from: http://zakon5.rada.gov. ua/ laws/show/775-2015-п. Ukrainian.

33. Guidelines for iodine prophylaxis following nuclear accidents. World Health Organization. Regional Office for Europe. Copenhagen: FADL; 1989. [Electronic resource]. Available from: [https://trove.nla.gov.au/ work/5766789?q\&versionld $=6704323$.

34. Guidelines for lodine Prophylaxis following Nuclear Accidents. Update 1999. World Health Organization, Geneva,
1999 (WHO/SDE/PHE/99. 6). [Electronic resource]. Available from: http://www.who.int/ionizing_radiation/pub_meet/ lodine_Prophylaxis_guide. pdf.

35. Actual problems of iodine prophylaxis in Ukraine in the event of a radiation accident at a nuclear power plant: Analytical note National Institute for Strategic Studies. [Актуальні проблеми йодної профрілактики в Україні на випадок радіаційної аварії на АЕС: Аналітична записка Національний інститут стратегічних досліджень]. [Electronic resource]. Available from: http://www. niss.gov.ua/ articles/2374/. Ukrainian.

36. Skaletskyi YuM, Savytskyi VL, Pechyborshch VP. [Problems of iodine prophylaxis in Ukraine in the event of a radiation accident at the nuclear power plant]. Visnyk problem biolohii i medytsyny. 2014;3(1): 321-5. Ukrainian.

37. Honcharov SF, Avetysov HM, Serdiuk AM, Los IP, Tarasiuk OE. [Problems of conducting iodine prophylaxis in the event of an accident at the nuclear unit of the nuclear power plant]. Dovkillia ta zdorovia. 2013;1: 12-19. Russian.

38. Order of the State Nuclear Regulatory Committee No. 154, dated November 8, 2011 "On Approval of the Procedure for Immediate Measures of Iodine Prevention in the Population of Ukraine in the Event of a Radiological Accident". [Electronic resource]. Available from: http://zakon2. rada.gov.ua/laws/ show/z1353-11. Ukrainian.

Отримано 03.05.2018

ISSN 2312-0967. Pharmaceutical review. 2018. № 3 